Article

\title{
Brain Pathology in Mucopolysaccharidoses (MPS) Patients with Neurological Forms
}

\author{
Gustavo M. Viana ${ }^{1,2}{ }^{\oplus}$, David A. Priestman ${ }^{3}$, Frances M. Platt ${ }^{3}{ }^{\circledR}$, Shaukat Khan ${ }^{4}$, \\ Shunji Tomatsu ${ }^{4}$ and Alexey V. Pshezhetsky ${ }^{1,2,3, * \mathbb{D}}$ \\ 1 Division of Medical Genetics, CHU Ste-Justine Research Centre, Montreal, QC H3T 1C5, Canada; \\ gvianabiomed@gmail.com \\ 2 Department of Biochemistry, Federal University of São Paulo (UNIFESP), São Paulo 04044-020, SP, Brazil \\ 3 Department of Pharmacology, University of Oxford, Oxford OX1 3SZ, UK; \\ david.priestman@pharm.ox.ac.uk (D.A.P.); frances.platt@pharm.ox.ac.uk (F.M.P.) \\ 4 Nemours/Alfred I. duPont Hospital for Children, Wilmington, DE 19801, USA; \\ Shaukat.Khan@nemours.org (S.K.); Shunji.Tomatsu@nemours.org (S.T.) \\ * Correspondence: alexei.pchejetski@umontreal.ca; Tel.: +1-514-345-4931 (ext. 2736)
}

Received: 23 December 2019; Accepted: 27 January 2020; Published: 1 February 2020

\begin{abstract}
Mucopolysaccharidoses (MPS) are the group of lysosomal storage disorders caused by deficiencies of enzymes involved in the stepwise degradation of glycosaminoglycans. To identify brain pathology common for neurological MPS, we conducted a comprehensive analysis of brain cortex tissues from post-mortem autopsy materials of eight patients affected with MPS I, II, IIIA, IIIC, and IIID, and age-matched controls. Frozen brain tissues were analyzed for the abundance of glycosaminoglycans (heparan, dermatan, and keratan sulfates) by LC-MS/MS, glycosphingolipids by normal phase HPLC, and presence of inflammatory cytokines interleukin-6 (IL-6) and tumor necrosis factor superfamily member 10 (TNFSF10) by Western blotting. Fixed tissues were stained for the markers for microgliosis, astrogliosis, misfolded proteins, impaired autophagy, and GM2 ganglioside. Our results demonstrate that increase of heparan sulfate, decrease of keratan sulfate, and storage of simple monosialogangliosides 2 and 3 (GM2 and GM3) as well as the neutral glycosphingolipid, LacCer, together with neuroinflammation and neuronal accumulation of misfolded proteins are the hallmarks of brain pathology in MPS patients. These biomarkers are similar to those reported in the corresponding mouse models, suggesting that the pathological mechanism is common for all neurological MPS in humans and mice.
\end{abstract}

Keywords: mucopolysaccharidosis; brain pathology; neuroinflammation; glycosaminoglycans; glycosphingolipids; protein misfolding

\section{Introduction}

More than $30 \%$ of patients affected with lysosomal diseases have mucopolysaccharidoses (MPS), disorders affecting the enzymes involved in the stepwise degradation of glycosaminoglycans (GAGs) [1-4]. Seven MPS are caused by genetic deficiencies in enzymes participating in heparan sulfate (HS) catabolism. Three of them also have blocks in dermatan sulfate (DS) degradation, therefore resulting in accumulation of both DS and HS [5]: MPS I (Hurler-Scheie syndrome, $\alpha$-iduronidase deficiency), MPS II (Hunter syndrome, iduronate sulfatase deficiency), and MPS VII (Sly syndrome, glucuronidase deficiency). Defects in the remaining four enzymes, $\alpha$-N-acetylglucosaminidase, heparan $\mathrm{N}$-sulfatase, HGSNAT, and $\mathrm{N}$-acetylglucosamine 6-sulfatase, cause blocks only in the catabolism of HS. They are classified as variants of a single disorder, MPS III or Sanfilippo syndrome [5]. Other forms of MPS are associated with storage of DS and chondroitin sulfate, such as MPS VI, or keratan sulfate (KS), such as MPS IV, but neurological manifestations are caused only by accumulation of HS. 
The variability in behavioral phenotypes for particular MPS subtypes is striking. The behavior of MPS I and MPS VII patients is generally normal and even the severely affected children are usually placid, calm, and sometimes overcautious, whereas MPS III patients show hyperactivity, aggressive behavior, insomnia, and autistic features such as lack of fear $[5,6]$. The neurological phenotype of MPS II is highly variable from severe in rapidly progressing cases to mild or even absent in slowly progressing cases [7]. No specific therapy is currently approved for neurological MPS, making them the biggest group of untreatable lysosomal diseases; however, numerous preclinical studies and clinical trials are being conducted [8].

Understanding the pathological basis underlying the central nervous system (CNS) manifestations in neurological MPS is crucial for developing novel therapies. Besides, it allows the identification of specific biomarkers of the disease both for monitoring disease progression and determining the efficacy of new therapies. Previous studies provided evidence that the accumulation of HS in neurological MPS triggers a multifaceted mechanism leading to neuronal malfunctioning and eventually to neurodegeneration. This mechanism involves general inflammation reactions, release of multifunctional cytokines and oxidative stress, pathological changes in the mitochondrial system and vesicular transport, progressive accumulation of lipid and protein aggregates, and closely resembles pathological cascades in age-related neurodegenerative tauopathies [9-12]. While these studies provide crucial information essential for our understanding of the diseases, it is important to understand that the majority have been conducted using the animal (mainly mouse) models of the disease, sometimes demonstrating clinical phenotypes different from those of the human patients. For example, all three mouse models of Sanfilippo disease (MPS IIIA, IIIB, and IIIC) develop urinary retention incompatible with their survival for longer than 8-11 months and not present in the human patients [13-15]. The alpha-L-iduronidase knockout MPS I mice show extensive dysostosis [16] as well as a progressive motor dysfunction [17]; their neurological phenotype is considerably milder as compared with that of rapidly progressing Hurler patients [18]. Several studies described analysis of CNS tissues of human MPS patients; however, the majority of them involved only one (and rarely more than two) type of MPS, preventing comparison of the brain pathology across diseases [19].

In the current study, we report the first comprehensive analysis of frozen and fixed brain cortex tissues from post-mortem autopsy materials of eight patients affected with MPS I, II, IIIA, IIIC, and IIID as well as age-matched controls. Our results demonstrate that an increase of HS (HS/DS), a decrease of $\mathrm{KS}$, secondary lipidome changes, neuroinflammation, and protein folding defects are the most striking features of CNS pathology in MPS patients with neurological forms.

\section{Patients and Methods}

\subsection{Patients}

Ethical approval for the research involving human tissues was granted by Research Ethics Board (Comité d'éthique de la recherche numéro FWA00021692) of Centre hospitalier universitaire Sainte-Justine (CHU Ste.-Justine). The approval number is: 2020-2365. Frozen or fixed with PFA, cerebral tissues from MPS patients and age-matched controls were provided by National Institutes of Health (NIH) NeuroBioBank (project 1071, MPS Synapse) together with clinical descriptions and results of the neuropathological examination.

\subsection{Analysis of Brain Glycosaminoglycans by Targeted LC-MS/MS}

Disaccharides were produced from polymer GAGs by digestion with chondroitinase B, heparitinase, and keratanase II, resulting in DS (di-OS), HS (diHS-NS, diHS-0S), and KS (mono-sulfated KS, di-sulfated KS). The enzymes were obtained from Seikagaku Corporation (Tokyo, Japan), and chondrosine was used as an internal standard (IS). Unsaturated disaccharides, $\triangle$ DiHS-NS, 2-deoxy-2-sulfamino-4-O-(4-deoxy-a-L-threo-hex-4-enopyranosyluronicacid)-D-glucose; $\triangle \mathrm{DiHS}$-0S, 2-acetamido-2-deoxy-4-O-(4-deoxy-a- $L$ threo-hex-4-enopyranosyluronicacid)-D-glucose; $\triangle \mathrm{Di}-4 \mathrm{~S}$ (DS), 
2-acetamido-2-deoxy-4-O-(4-deoxy-a- $L$-threo-hex-4-enopyranosyluronic acid)-4-O-sulfo- $D$-glucose; mono-sulfated KS, Gal $\beta 1-4 G l c N A c(6 S)$ and di-sulfated KS, Gal (6S) $\beta 1-4 G l c N A c(6 S)$ were obtained from Seikagaku Corporation (Tokyo, Japan) and used to make standard curves. Stock solutions of $\Delta$ DiHS-NS $(100 \mu \mathrm{g} / \mathrm{mL}), \Delta$ DiHS-0S $(100 \mu \mathrm{g} / \mathrm{mL}), \Delta$ Di-4S $(250 \mu \mathrm{g} / \mathrm{mL})$, mono- and di-sulfated KS $(1000 \mu \mathrm{g} / \mathrm{mL})$, and IS $(5 \mu \mathrm{g} / \mathrm{mL})$ were prepared separately in Milli-Q water. Standard solutions of $\Delta$ DiHS-NS, $\triangle$ DiHS-0S, $\Delta$ Di-4S $(7.8125,15.625,31.25,62.5,125,250,500$, and $1000 \mathrm{ng} / \mathrm{mL})$, and monoand di-sulfated KS $(80,160,310,630,1250,2500,5000$, and $10000 \mathrm{ng} / \mathrm{mL})$ were each mixed with IS solution $(5 \mu \mathrm{g} / \mathrm{mL})$.

Frozen brain tissues (40-60 mg) were homogenized in $1.5 \mathrm{~mL}$ cold acetone for $10 \mathrm{sec}$ using Polytron (Mount Holly, NJ). Homogenates were transferred to $2 \mathrm{~mL}$ Eppendorf tubes and kept at $-80^{\circ} \mathrm{C}$ for $20 \mathrm{~min}$. Samples were centrifuged for $30 \mathrm{~min}$ at $12,000 \times g$ at $4{ }^{\circ} \mathrm{C}$. The acetone was removed and pellets were dried in a vacuum centrifuge. The pellets were resuspended in $200 \mu \mathrm{L}$ of $0.5 \mathrm{~N} \mathrm{NaOH}$ and incubated at $50{ }^{\circ} \mathrm{C}$ for $2 \mathrm{~h}$. Samples were neutralized with $100 \mu \mathrm{L}$ of $1 \mathrm{~N} \mathrm{HCl}$ to $\mathrm{pH}$ 7.0. Sodium chloride was added to a final concentration of $3 \mathrm{M}$, followed by centrifugation at 10,000 $\mathrm{g}$ for $5 \mathrm{~min}$ at a room temperature (RT). The supernatants were transferred to new tubes, and $83.3 \mu \mathrm{L}$ of $1 \mathrm{~N} \mathrm{HCl}$ was added to make $\mathrm{pH}$ acidic (around 1.0). Then, tubes were centrifuged at $10,000 \times g$ for $5 \mathrm{~min}$ at RT. The supernatants were transferred to the new tubes and $83.3 \mu \mathrm{L}$ of $1 \mathrm{~N} \mathrm{NaOH}$ was added to increase $\mathrm{pH}$ to 7.0. The samples were diluted 2 -fold with $1.3 \%$ potassium acetate in $100 \%$ ethanol and centrifuged at $12,000 \times g$ for $30 \mathrm{~min}$ at $4{ }^{\circ} \mathrm{C}$. Supernatants were removed and pellets washed with $80 \%$ cold ethanol. Finally, the pellets were dried at RT, dissolved in $100 \mu \mathrm{L}$ of $50 \mathrm{mM}$, Tris- $\mathrm{HCl}$ buffer (pH 7.0), and kept at $-20^{\circ} \mathrm{C}$.

Ten microliters of each brain sample or standard and $90 \mu \mathrm{L}$ of $50 \mathrm{mM}$ Tris- $\mathrm{HCl}$ buffer (pH 7.0) were transferred to the wells of AcroPrep ${ }^{\mathrm{TM}}$ Advance 96-Well Filter Plates with Ultrafiltration Omega $10 \mathrm{~K}$ membrane filters (PALL Corporation, NY, USA). Then, $40 \mu \mathrm{L}$ of the solution containing chondroitinase B (0.5 mU/sample), heparitinase and keratanase II (both, $1 \mathrm{mU} / \mathrm{sample})$, and IS solution $(5 \mu \mathrm{g} / \mathrm{mL})$ followed by $60 \mu \mathrm{L}$ of $50 \mathrm{mM}$ Tris-hydrochloric acid buffer were also added to each well. The filter plate was placed on a 96-well plate, incubated at $37^{\circ} \mathrm{C}$ overnight and centrifuged at $2500 \times \mathrm{g}$ for $15 \mathrm{~min}$.

The chromatographic system consisted of 1260 Infinity Degasser, binary pump, autoinjector, thermostatic column compartment, and 1290 Infinity Thermostat (Agilent Technologies, Palo Alto, CA, USA) and a Hypercarb column (2.1 mm internal diameter (i.d.) $50 \mathrm{~mm}, 5 \mu \mathrm{m}$, Fisher Scientific, Pittsburg, PA, USA) with hypercarb guard ( $2.1 \mathrm{~mm}$ i.d. $10 \mathrm{~mm}, 5 \mu \mathrm{m}$, Cole-Parmer, IL, USA). The column temperature was kept at $60{ }^{\circ} \mathrm{C}$. The mobile phases were $100 \mathrm{mM}$ ammonia (A) and $100 \%$ acetonitrile (B). The gradient conditions were programmed as follows: The initial composition of $100 \%$ A was held for $1 \mathrm{~min}$, linearly modified to $30 \%$ B by $4 \mathrm{~min}$, maintained at $30 \% \mathrm{~B}$ until $5.5 \mathrm{~min}$, returned to $0 \%$ B by $6 \mathrm{~min}$, and maintained at $0 \%$ B until $10 \mathrm{~min}$. The flow rate was $0.7 \mathrm{~mL} / \mathrm{min}$. The 6460 Triple Quad mass spectrometer (Agilent Technologies) was operated in the negative ion detection mode with thermal gradient focusing electrospray ionization (Agilent Jet Stream technology, AJS). The parameters of jet stream technology were as follows: Drying gas temperature, $350{ }^{\circ} \mathrm{C}$; drying gas flow, $11 \mathrm{~L} / \mathrm{min}$; nebulizer pressure, $58 \mathrm{psi}$; sheath gas temperature, $400{ }^{\circ} \mathrm{C}$; sheath gas flow, $11 \mathrm{~L} / \mathrm{min}$; capillary voltage, $4000 \mathrm{~V}$; and nozzle voltage, 2,000 V. Specific precursor and product ions, mass/charge $(\mathrm{m} / \mathrm{z})$, values were used to quantify each disaccharide: IS, 354.3, 193.1; DS, 378.3, 175.1; mono-sulfated KS, 462, 97; di-sulfated KS, 542, 462; diHS-NS, 416, 138; and diHS-0S, 378.3, 175.1. DS was measured as di-0S after the digestion of di-4S by a $4 \mathrm{~S}$-sulfatase present in the preparation of chondroitinase $\mathrm{B}$. The injection volume was $5 \mu \mathrm{L}$ with a total run time of $10 \mathrm{~min}$ per sample. The peak areas for all components were integrated automatically using QQQ Quantitative Analysis software (Agilent Technologies), and peak area ratios (area of analyses/area of IS) were plotted against concentration by weighted linear regression. Raw data of LC-MS/MS were automatically preserved. The concentration of each disaccharide was calculated using QQQ Quantitative Analysis software. 


\subsection{Analysis of Brain Glycosphingolipids by HPLC}

Glycosphingolipids (GSLs) were isolated and analyzed essentially as described [20]. Brain tissues were homogenized in CHU Ste.-Justine in water using an Ultra-Turrax T25 probe homogenizer (IKA, Germany) and sent to Oxford for the analysis of brain glycosphingolipids. Protein concentrations in the homogenates were determined using bicinchoninic acid (BCA) assay (Sigma, UK). Lipids from the homogenates were then extracted with chloroform/methanol, and GSLs were further purified using solid-phase C18 columns (Telos, Kinesis, UK). Eluted lipid fraction GSLs were dried under nitrogen and digested overnight with recombinant endoglycoceramidase I, kindly supplied by Orphazyme. The released glycans were then fluorescently labelled with anthranilic acid (2AA) prior to purification using DPA-6S SPE (Solid Phase Extraction) amide columns (Supelco, PA, USA). Purified, 2AA-labelled glycans were then separated and quantified by normal-phase high-performance liquid chromatography (NP-HPLC) as described previously [20]. In order to calculate GSL molar quantities, 2.5 pmol of a 2AA-labelled chitotriose standard (Ludger, UK) was also included in the HPLC sample group.

\subsection{Immunofluorescence and Confocal Microscopy}

Formalin-fixed human brains were embedded in optimum cutting temperature compound (OCT), cut into $40-\mu \mathrm{m}$-thick sections and stored at $-80^{\circ} \mathrm{C}$ in cryopreservation buffer $(0.05 \mathrm{M}$ sodium phosphate buffer, pH 7.4, 15\% sucrose, $40 \%$ ethylene glycol). For immunofluorescence analysis, brain slices were washed with phosphate-buffered saline (PBS), $\mathrm{pH} 7.4$, and blocked with $5 \%$ bovine serum albumin with $0.3 \%$ Triton X-100 for $1 \mathrm{~h}$. Slices were then incubated with the following primary antibodies: Rabbit anti-glial fibrillary acidic protein or GFAP/8-1E7 (1:200, 8-1E7, deposited to the Developmental Studies Hybridoma Bank by De Blas, Angel L.; information available at https://dshb.biology.uiowa.edu/8-1E7), rabbit anti-LC3B (1:200, GeneTex, Irvine, CA, USA; catalog number: GTX127375), and mouse humanized anti-GM2/KM966 (1:100, kindly provided by Dr. Nobuo Hanai, Dr. Akiko Furuya, and Kyowa Hakko Kirin Co., Ltd.). Secondary antibodies (Life Technologies, USA) were Alexa Fluor ${ }^{\circledR} 488$ donkey anti-rabbit IgG (catalog number: R37118) and Alexa Fluor ${ }^{\circledR} 633$ goat anti-mouse IgG (catalog number: A-21050). For microglia visualization, samples were labeled in situ (1:20) with isolectin B4 from Griffonia simplicifolia (GS-ILB4), AlexaFluor ${ }^{\mathrm{TM}} 568$ conjugate (ILB4, Life Technologies, USA, catalog number: I21412). For amyloid aggregates, brain slices were washed with PBS, incubated with $0.3 \%$ Triton X-100 in PBS for $1 \mathrm{~h}$ at RT and stained with $0.05 \%$ thioflavin S (Sigma, USA, catalog number: T1892) in PBS in the dark for $15 \mathrm{~min}$, washed in 50\% ethanol twice for $1 \mathrm{~min}$ and, then, in water for $3 \mathrm{~min}$. The slices were then mounted using Prolong Gold Antifade Mounting Medium with 4',6-diamidino-2-phenylindole (DAPI;Life Technologies, USA, catalog number: P36931). Representative images from the whole tissue were captured with a Leica TCS SP8 Confocal Laser Scanning Microscope (Leica Microsystems, $\mathrm{DE})$. Fluorescence observations were made through oil-immersion Plan-Apochromat 63x objectives (numerical aperture 1.4). Images were represented as maximum intensity projections corresponding to the z-series of all confocal stacks. Images were quantified using the ImageJ software (US National Institutes of Health, USA) and mounted and processed using Photoshop (Adobe Inc., USA). 


\subsection{Western Blots}

Brain tissues (frontal part of a hemisphere, approximately $25 \%$ of the brain) were homogenized in radioimmunoprecipitation assay (RIPA) buffer (50 mM Tris- $\mathrm{HCl}, \mathrm{pH} 7.4,150 \mathrm{mM} \mathrm{NaCl}, 1 \% \mathrm{NP}-40$, $0.25 \%$ sodium deoxycholate, $0.1 \%$ SDS, $2 \mathrm{mM}$ EDTA, $1 \mathrm{mM}$ phenylmethylsulfonyl fluoride (PMSF), Roche protease and phosphate inhibitor cocktails, $2.5 \mathrm{~mL}$ per $1 \mathrm{~g}$ of tissue). The homogenates were kept on ice for $30 \mathrm{~min}$ and centrifuged at $13,000 \mathrm{RPM}$ at $4{ }^{\circ} \mathrm{C}$ for $25 \mathrm{~min}$. The supernatant was collected and centrifuged again for $15 \mathrm{~min}$. Total protein concentration was measured using the Pierce BCA Protein Assay Kit (Thermo Fisher Scientific) and equalized. Protein extracts $(50 \mu \mathrm{g})$ were resolved by SDS-PAGE on 10\%-15\% gels (29:1 acrylamide/bis-acrylamide) and transferred to nitrocellulose membranes (Millipore, USA). Membranes were blocked with 5\% BSA in TBS-T (Tris-buffered saline with $0.1 \%$ Tween-20, $\mathrm{pH} 8.4$ ) for $1 \mathrm{~h}$ at room temperature and then incubated overnight at $4{ }^{\circ} \mathrm{C}$ with the following primary antibodies (diluted 1:1000 in TBS-T/1\% BSA): rabbit anti-AFFN-TNFSF10-11F2 (tumor necrosis factor superfamily member 10 or TNFSF10, deposited to the Developmental Studies Hybridoma Bank by EU Program Affinomics, catalog number: AFFN-TNFSF10-11F2, RRID:AB_2617959) and rabbit anti-CPTC-IL6-1 (IL-6; deposited to the DSHB by Clinical Proteomics Technologies for Cancer, catalog number: CPTC-IL6-1, RRID:AB_2617278). After several washings in TBS-T, membranes were incubated with horseradish peroxidase-conjugated anti-mouse IgG (1:2500, Cell Signaling Technologies, USA, catalog number: 7076), anti-rabbit IgG (1:2,500, Cell Signaling Technologies, USA, catalog number: 7074) or rabbit anti-goat IgG (1:10,000, Merck, USA, catalog number: A-8919). The immunoblots were revealed with Pierce enhanced chemiluminescence (ECL) Western blotting chemiluminescence substrate (Thermo Fisher Scientific, USA). Bands were quantified using ImageJ software (US National Institutes of Health, USA). Total GAPDH protein was used for data normalization.

\section{Results}

\subsection{Patients}

Frozen and/or paraformaldehyde (PFA)-fixed somatosensory cortex tissues from eight MPS patients (one MPS I, two MPS II, two MPS IIIA, one MPS IIIC, and two MPS IIID) and seven non-MPS, controls matched for age and sex, collected at post-mortem autopsy were obtained from National Institutes of Health (NIH) NeuroBioBank (project 1071, MPS Synapse). The age, the cause of death, sex, race, and available clinical and neuropathological information for the patients and controls are shown in Table 1. All MPS patients had complications from their primary disease and died in the first-third decades of life except MPS II patient 902, who was suffering from a non-neurological form of the disease and died at 42 years of age from MPS II-related pneumonia. None of the patients had received enzyme replacement therapy (ERT) or hematopoietic stem cell transplantation (HSCT). Among non-MPS controls, two died of accident-related injuries, two of asthma complications, two of atherosclerotic cardiovascular disease, and one of smoke inhalation (Table 1). 
Table 1. Mucopolysaccharidoses (MPS) patients and control subjects used in the study.

\begin{tabular}{|c|c|c|c|c|c|c|c|c|}
\hline UMBN & GUID & Disorder & $\begin{array}{c}\text { Cause of } \\
\text { Death }\end{array}$ & $\begin{array}{c}\text { Age: Years, } \\
\text { Days }\end{array}$ & Sex & Race & Clinical Information & Neuropathologic Findings \\
\hline 561 & NDAR_INVYV182KRN & $\begin{array}{l}\text { MPS I, Hurler } \\
\text { Syndrome }\end{array}$ & $\begin{array}{l}\text { Complications } \\
\text { of disorder }\end{array}$ & 6,265 & Female & Caucasian & $\begin{array}{l}\text { Was oxygen dependent; had } \\
\text { hydrocephalus, cardiomyopathy, } \\
\text { chronic sinusitis, ear infections, } \\
\text { blindness, hearing impairment, } \\
\text { numerous pneumonias and } \\
\text { hernias. }\end{array}$ & $\begin{array}{l}\text { Neocortex with distended, "ballooned" } \\
\text { neurons with mucin- and Alcian-blue } \\
\text { positive material, also present throughout } \\
\text { the central nervous system; occasional } \\
\text { perivascular macrophages with similar } \\
\text { material in the white matter; EM shows } \\
\text { typical "zebra bodies" seen in } \\
\text { mucopolysaccharidoses. }\end{array}$ \\
\hline 902 & NDAR_INVTG497HU7 & $\begin{array}{l}\text { MPS II, Hunter } \\
\text { Syndrome }\end{array}$ & $\begin{array}{l}\text { Complications } \\
\text { of disorder }\end{array}$ & 42,134 & Male & Caucasian & $\begin{array}{l}\text { Had multiple complications } \\
\text { related to Hunter's syndrome, } \\
\text { including tracheobronchial } \\
\text { malacia, recurrent bronchitis and } \\
\text { pneumonia, had multiple repairs } \\
\text { of anterior abdominal wall hernia, } \\
\text { was blind and somewhat deaf, had } \\
\text { bilateral carpal tunnel release, } \\
\text { history of mitral and aortic } \\
\text { insufficiency, congestive heart } \\
\text { failure. }\end{array}$ & $\begin{array}{l}\text { Gliosis with axonal degeneration, optic } \\
\text { nerves bilaterally, with neuronal loss and } \\
\text { gliosis, lateral geniculate nucleus, old } \\
\text { hemorrhagic cystic infarct, right occipital } \\
\text { cortex and white matter, periventricular } \\
\text { benign epidermal cyst, right occipital. }\end{array}$ \\
\hline 3617 & NDAR_INVFP950EUM & $\begin{array}{c}\text { MPS IIIA, } \\
\text { Sanfilippo A } \\
\text { Syndrome }\end{array}$ & $\begin{array}{l}\text { Complications } \\
\text { of disorder }\end{array}$ & 12,38 & Female & Caucasian & N/A & $\begin{array}{l}\text { Neurons throughout the brain have } \\
\text { enlarged cell bodies with foamy } \\
\text { cytoplasm, mild gliosis and status } \\
\text { spongiosis in adjacent parenchyma, these } \\
\text { neuronal changes are particularly severe } \\
\text { in cerebral cortex, Purkinje cell layer of the } \\
\text { cerebellum and substantia nigra. The } \\
\text { choroid plexus epithelial cells are similarly } \\
\text { affected with slightly enlarged and } \\
\text { vacuolated cytoplasm. The centrum } \\
\text { semi-ovale is mildly gliotic, its } \\
\text { perivascular spaces dilated, fibrotic and } \\
\text { contain glitter cells and occasional } \\
\text { lymphocytes. }\end{array}$ \\
\hline
\end{tabular}


Table 1. Cont.

\begin{tabular}{|c|c|c|c|c|c|c|c|c|}
\hline UMBN & GUID & Disorder & $\begin{array}{c}\text { Cause of } \\
\text { Death }\end{array}$ & $\begin{array}{l}\text { Age: Years, } \\
\text { Days }\end{array}$ & Sex & Race & Clinical Information & Neuropathologic Findings \\
\hline 563 & NDAR_INVRR063YHC & $\begin{array}{l}\text { MPS IIIA, } \\
\text { Sanfilippo A } \\
\text { Syndrome }\end{array}$ & $\begin{array}{l}\text { Complications } \\
\text { of disorder }\end{array}$ & 11,101 & Female & Caucasian & $\begin{array}{l}\text { Two years before the death was } \\
\text { attending school although having } \\
\text { trouble walking and eating, by the } \\
\text { time of death was non-verbal with } \\
\text { deteriorating psychomotor skills, } \\
\text { self-injurious behavior, had } \\
\text { problems with sleep and agitation, } \\
\text { suffered from mitral valve } \\
\text { prolapse with myxomatous } \\
\text { changes and mild regurgitation. }\end{array}$ & N/A \\
\hline 6194 & & $\begin{array}{c}\text { MPS IIIC, } \\
\text { Sanfilippo C } \\
\text { Syndrome }\end{array}$ & $\begin{array}{c}\text { Acute } \\
\text { pneumonia } \\
\text { as a } \\
\text { consequence } \\
\text { of disorder }\end{array}$ & 20,95 & Male & African-American & $\begin{array}{c}\text { Had a history of developmental } \\
\text { delays, Nissen fundoplication and } \\
\text { G-tube, asthma, seizures, sleep } \\
\text { problems, agitation, used hearing } \\
\text { aids. }\end{array}$ & $\begin{array}{l}\text { The brain showed cerebral atrophy, mild } \\
\text { hydrocephalus, neuronal enlargement } \\
\text { with positive cytoplasmic PAS, Alcian blue } \\
\text { and LFB, perivascular cuffing of foamy } \\
\text { macrophages, white matter vacuolation. }\end{array}$ \\
\hline 5411 & NDAR_INVAB442TCG & $\begin{array}{l}\text { MPS IIID, } \\
\text { Sanfilippo D } \\
\text { Syndrome }\end{array}$ & $\begin{array}{l}\text { Complications } \\
\text { of disorder }\end{array}$ & 24,280 & Female & Caucasian & $\begin{array}{l}\text { One of two siblings suffering from } \\
\text { Sanfilippo D, had a progressive } \\
\text { neurologic decline with loss of } \\
\text { vision, verbal expression, } \\
\text { continence; had rare seizures in } \\
\text { spite of anticonvulsive treatment } \\
\text { and was wheelchair bound for the } \\
\text { last year of life. }\end{array}$ & $\begin{array}{l}\text { Generalized cerebral atrophy and } \\
\text { neuronal storage disorder. }\end{array}$ \\
\hline 5424 & NDAR_INVUC095YP2 & $\begin{array}{l}\text { MPS IIID, } \\
\text { Sanfilippo D } \\
\text { Syndrome }\end{array}$ & $\begin{array}{l}\text { Complications } \\
\text { of disorder }\end{array}$ & 23,149 & Female & Caucasian & $\begin{array}{l}\text { One of two siblings suffering from } \\
\text { Sanfilippo D, had a progressive } \\
\text { decline in hearing, verbal and } \\
\text { visual abilities, had no specific } \\
\text { cardiopulmonary symptomatology, } \\
\text { no seizures, wheelchair bound for } \\
\text { the last two years of life. }\end{array}$ & $\begin{array}{l}\text { Generalized cerebral atrophy and } \\
\text { neuronal storage disorder. }\end{array}$ \\
\hline HBCB_18_01_OC & & $\begin{array}{l}\text { MPS II, Hunter } \\
\text { Syndrome }\end{array}$ & $\begin{array}{l}\text { Complications } \\
\text { of disorder }\end{array}$ & 13,0 & Male & Caucasian & $\begin{array}{l}\text { Had a history of developmental } \\
\text { delays, scoliosis, asthma, } \\
\text { tracheomalacia, GERD, seizures } \\
\text { and mild aortic regurgitation. }\end{array}$ & $\begin{array}{l}\text { Diffuse neuronal loss, gliosis in the cortex; } \\
\text { abundant swollen neurons, greatest in the } \\
\text { parietal and occipital cortex; severe } \\
\text { neuronal loss and gliosis in the thalamus; } \\
\text { depletion of processes and varying gliosis } \\
\text { in the cerebellum. }\end{array}$ \\
\hline 662 & NDAR_INVCK582GNX & $\begin{array}{l}\text { Unaffected } \\
\text { Control }\end{array}$ & $\begin{array}{l}\text { Accident, } \\
\text { multiple } \\
\text { injuries }\end{array}$ & 12,356 & Female & Caucasian & & N/A \\
\hline
\end{tabular}


Table 1. Cont.

\begin{tabular}{cccccccc}
\hline UMBN & GUID & Disorder & $\begin{array}{c}\text { Cause of } \\
\text { Death }\end{array}$ & $\begin{array}{c}\text { Age: Years, } \\
\text { Days }\end{array}$ & Sex & Race & Clinical Information \\
\hline 754 & NDAR_INVJV820CBR & $\begin{array}{c}\text { Unaffected } \\
\text { Control }\end{array}$ & Asthma & 11,201 & Female & $\begin{array}{c}\text { Native } \\
\text { Hawaiian/Pacific } \\
\text { Islander }\end{array}$ & N/A \\
\hline 1266 & NDAR_INVCX672EJ2 & $\begin{array}{c}\text { Unaffected } \\
\text { Control }\end{array}$ & $\begin{array}{c}\text { Arteriosclerotic } \\
\text { cardiovascular } \\
\text { disease }\end{array}$ & 42,0 & Male & Caucasian \\
\hline 5641 & NDAR_INVNG087HR2 & $\begin{array}{c}\text { Unaffected } \\
\text { Control }\end{array}$ & $\begin{array}{c}\text { Acute } \\
\text { asthma }\end{array}$ & 24,288 & Female & African-American \\
\hline 5287 & NDAR_INVUB832RTY & $\begin{array}{c}\text { Unaffected } \\
\text { Control }\end{array}$ & $\begin{array}{c}\text { Multiple } \\
\text { injuries }\end{array}$ & 23,195 & Female & Caucasian & N/A A \\
\hline 5813 & NDAR_INVWA136XNT & $\begin{array}{c}\text { Unaffected } \\
\text { Control }\end{array}$ & $\begin{array}{c}\text { Atherosclerotic } \\
\text { cardiovascular } \\
\text { disease }\end{array}$ & 20,362 & Male & African-American \\
\hline 5977 & NDAR_INVAX199AGW & $\begin{array}{c}\text { Unaffected } \\
\text { Control }\end{array}$ & $\begin{array}{c}\text { Smoke } \\
\text { inhalation }\end{array}$ & 6,248 & Female & Caucasian & N/A \\
\hline
\end{tabular}




\subsection{Changes in GAG Profiles}

To study the impact of the deficiencies of the enzymes involved in catabolism of GAGs, we analyzed their levels in brain cortex tissues. Tandem mass spectrometry (LC-MS/MS) was used to determine the concentration of disaccharides derived from the three GAGs known to accumulate in MPS diseases: $\triangle \mathrm{Di}-0 \mathrm{~S}$ (DS), $\triangle \mathrm{DiHS}-\mathrm{NS}$, and $\triangle \mathrm{DiHS}-0 \mathrm{~S}$ (HS), as well as mono-sulfated and di-sulfated KS. Disaccharides were produced by specific enzyme digestion of each GAG, and quantified by negative-ion mode of multiple reaction monitoring. Analyses of the data demonstrated that the GAG profiles in control brains were significantly different from those of the patients with neurological MPS (Figure 1A). In control brain tissues, mono-sulfated KS was the most abundant, followed by $\Delta \mathrm{Di}-0 \mathrm{~S}$, $\triangle$ DiHS-0S, and $\triangle$ DiHS-NS. In the cortex tissues of all MPS patients, we observed increased levels of $\Delta$ DiHS-NS (2.15 median value in the patients vs 0.84 in controls, $p=0.0012$ in Mann-Whitney test) and $\Delta$ DiHS-0S (7.0, patients, vs. 1.38, controls, $p=0.0003$ ). At the same time, the levels of mono-sulfated and di-sulfated KS were reduced in all MPS patients (mono-sulfated KS, 1.15, patients, vs. 6.70, controls, $p=0.0003$; di-sulfated KS, 0.069 , patients, vs. 0.144 , controls, $p=0.0003$ ).

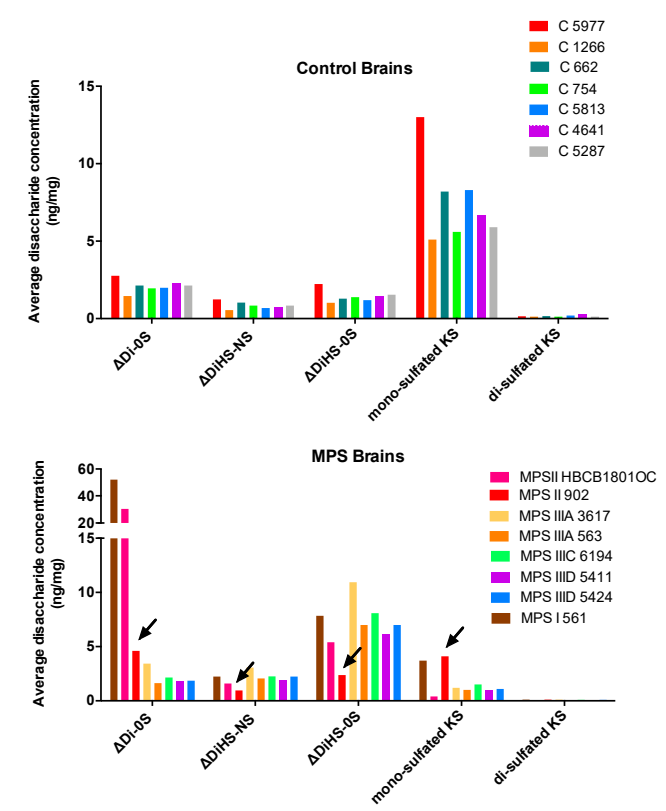

(A)

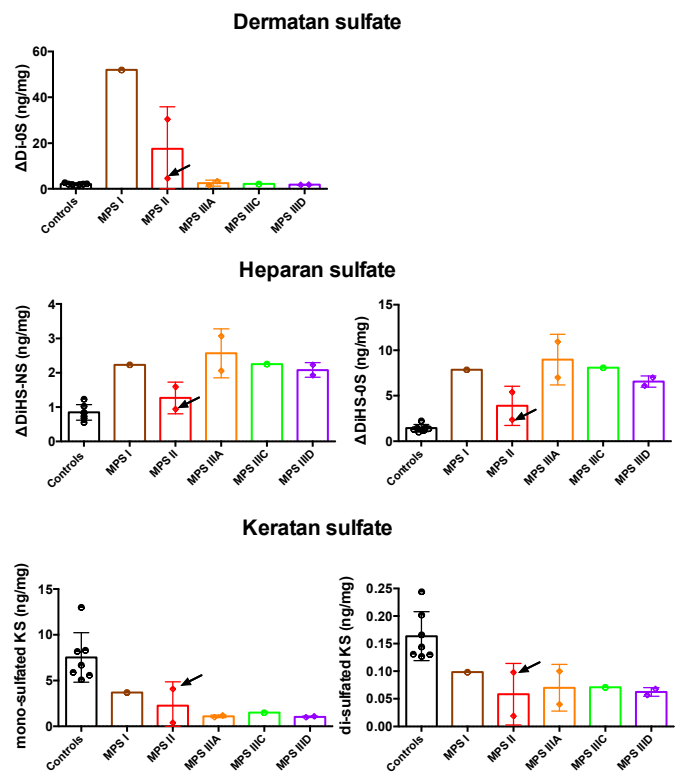

(B)

Figure 1. Glycosaminoglycans (GAGs) levels in the brains of mucopolysaccharidosis patients and controls. Levels of disaccharides produced by enzymatic digestion of dermatan sulfate (DS) ( $\triangle \mathrm{Di}-0 \mathrm{~S}$, $\triangle$ DiHS-NS) and heparan sulfate (HS) ( $\triangle$ DiHS-0S) as well as mono-sulfated and di-sulfated keratan sulfate (KS) were measured by tandem mass spectrometry and expressed (A) for the individual MPS patients and controls or (B) grouped according to the type of MPS disorder. Statistical significance of changes was estimated using Mann-Whitney multiple comparison test. Arrows indicate values detected in the tissues of non-neurological MPS II patient 902.

Analyses of the GAG levels in individual patients (Figure 1B) confirmed that DS increased only in the MPS I and MPS II, but not in MPS III patients. Levels of DS in the two MPS II patients were significantly different; the non-neurological MPS II patient 902 had $~ 7$-fold lower levels (marked with an arrowhead in Figure 1A,B) of DS than the MPS II patient HBCB1801OC who died at the age of 13 years, suffering from a more severe MPS II form with a CNS involvement. All patients, except the non-neurological MPS II patient 902, showed significantly increased levels of brain HS and decreased levels of KS. 


\subsection{Alteration of Glycosphingolipid Profiles}

The glycan chains of total glycosphingolipids extracted from the brain tissues were fluorescently labelled with anthranilic acid and analyzed by normal-phase HPLC. Quantification of chromatograms demonstrated that brain glycosphingolipid composition was significantly altered in the MPS patients. The control brain samples were dominated by four ganglioside species: GM1a (Monosialoganglioside) (35.2 $\pm 2.1 \%)$, GD1a (Disialoganglioside) $(26.9 \pm 2.3 \%)$, GD1b $(13.9 \pm 1.2 \%)$, and GT1b (Trisialoganglioside) $(9.4 \pm 0.9 \%)$. They were present at comparable levels, together representing $\sim 85 \%$ of brain glycosphingolipids (Figure $2 \mathrm{~A}$ ). This correlated well with previously published rodent data [21]. Besides these four major species, we were able to identify 13 minor Glycosphingolipid (GSL) species of which only 4 exceed $1 \%$ of total glycolipids: LacCer $(3.5 \pm 1.2 \%)$, GM2 $(2.3 \pm 0.1 \%)$, $\alpha-2,6-\mathrm{SpGb}$ and GD3 (both $1.7 \%$ ) and GM3 (1.05 $\pm 0.6 \%)$.

A
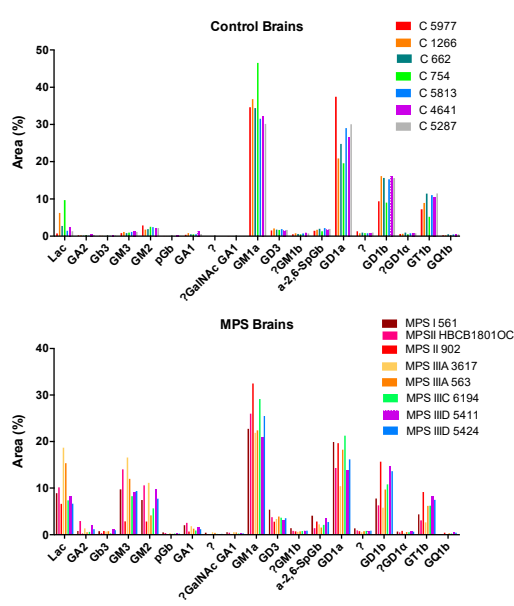

B



C

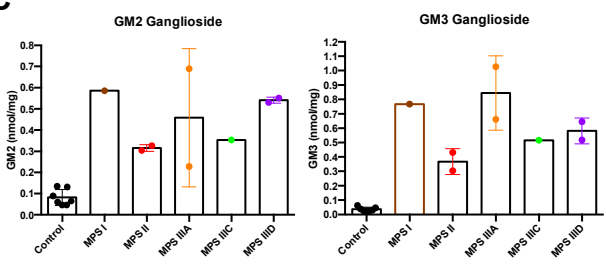

D

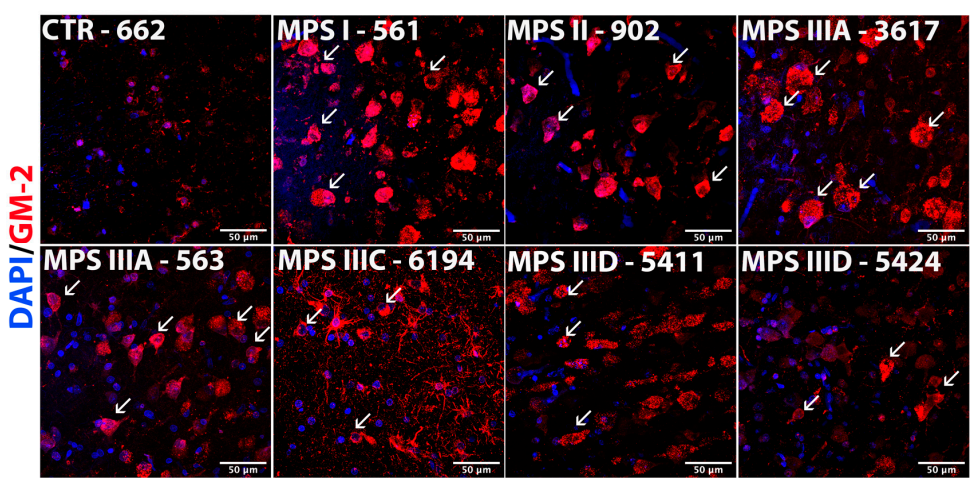

Figure 2. Sphingolipid levels in the brains of MPS patients and controls. Levels of glycans produced by enzymatic cleavage of total sphingolipid extracts of MPS patients and controls were measured by normal HPLC and plotted for the individual MPS patients and controls (A) or grouped for all patients and controls (B). The values show percentage of the specific lipid. The "?" means that the identity of the sphingolipid was unknown, or could not be confirmed. Statistical significance of changes was estimated using Mann-Whitney multiple comparison test $\left({ }^{*} p<0.05\right)$. (C) Levels of simple GM2 and GM3 gangliosides grouped according to the type of MPS disorder. (D) Confocal microscopy images of brain cortex tissues of MPS I (561), MPS II (902), MPS IIIA (3617 and 563), MPS IIIC (6194), and MPS IIID (5411 and 5424) patients and a representative control (662) stained with antibodies against GM2 (red). The fixed brain tissues of the MPS II patient HBCB1801OC were not sufficiently preserved to perform cryosectioning and conduct immunofluorescent analysis. 4' ,6-Diamidino-2-phenylindole (DAPI, blue) was used as the nuclear counterstain. Neurons with GM2 storage are shown with arrowheads. Scale bar: $50 \mu \mathrm{m}$. 
The glycosphingolipid composition was greatly altered in the brains of the MPS patients. The relative levels of three of four major complex gangliosides were significantly reduced. GM1a is reduced from $35.2 \pm 2.1$ to $25.1 \pm 1.4 \%$ ( $p=0.0012$ in multiple comparison t-test), GD1a, from $26.9 \pm 2.3$ to $16.7 \pm 1.3 \%$ ( $p=0.0015)$, and GT1b from $9.4 \pm 0.9 \%$ to $5.9 \pm 0.8(p=0.015)$. GD1b also showed a trend for decrease, but it was not statistically significant. In contrast, simple gangliosides GM2, GM3, and LacCer became major components in the MPS brain samples (GM2 7.4 $\pm 1.081,3.2$-fold increase, $p=0.0006$; GM3 $10.3 \pm 1.5,10$-fold increase, $p=5.2 \mathrm{e}^{-005}$; LacCer, $10.3 \pm 1.6$, 3-fold increase, $p=0.006$ ).

In addition, several glycolipids showed significant increases but still remained to be relatively minor components of the cortical tissue (GD3 increased from 1.75 to $3.7 \%, p=2.5 \mathrm{e}^{-005}$; Gb3, from 0.16 to $0.72 \%, p=0.0003$; GA1, from 0.69 to $1.51 \%, p=0.007$; and GA2, from 0.27 to $1.22 \%, p=0.017$ ). Importantly, the glycosphingolipid composition of the brain tissues of non-neurological MPS II patient 902 resembled more those of controls, than of MPS patients (GM1a 32.5\%, GD1a 19.6\%, GD1b 15.7\%, and GT1b 9.1\%). His tissues also showed slight elevation of LacCer (6\%) and GM3 (2.8\%) but not GM2 ganglioside $(2.86 \%$, marked with arrowheads on Figure $2 \mathrm{~B})$. When absolute values of simple GM2 and GM3 gangliosides were grouped according to the type of MPS disorder (Figure 2C), they showed remarkable resemblance to those of HS with higher levels in MPS I and, somewhat, lower levels in MPS II.

Accumulation of GM2 ganglioside in brain tissues was further confirmed by immunohistochemistry using the human-mouse chimeric monoclonal antibody, KM966 [22]. Numerous cells resembling by shape the pyramidal neurons and showing intensive staining by the antibody were present in the deep cortex layers of all MPS patients while being almost undetectable in the brain tissues of controls (Figure 2D).

\subsection{Microastroglyosis and Neuroinflammation}

The number of Glial fibrillary acidic protein (GFAP)-positive astrocytes and ILB4-positive microglia cells was augmented in all studied human MPS cortex tissues except for those of the non-neurological MPS II patient 902 (Figure 3A), suggesting that neuroinflammation previously reported in all mouse models was also heavily present in human patients. To test this further, we measured the protein levels of the inflammatory cytokines, IL-6, previously shown to be increased in patients and animal models across several MPS disorders [23-25]. We have also measured the levels of TNFSF10 (TRAIL), which has been associated with neuroinflammation in adult neurodegenerative diseases including Alzheimer's disease and multiple sclerosis [26,27]. We found that in the majority of MPS samples, levels of IL-6 and TRAIL proteins showed a trend for an increase. Levels of both IL-6 and TRAIL were significantly increased when the group of all MPS patients was compared with the group of controls $(p=0.04$ and $p=0.006$ in Mann-Whitney test, respectively). 
A
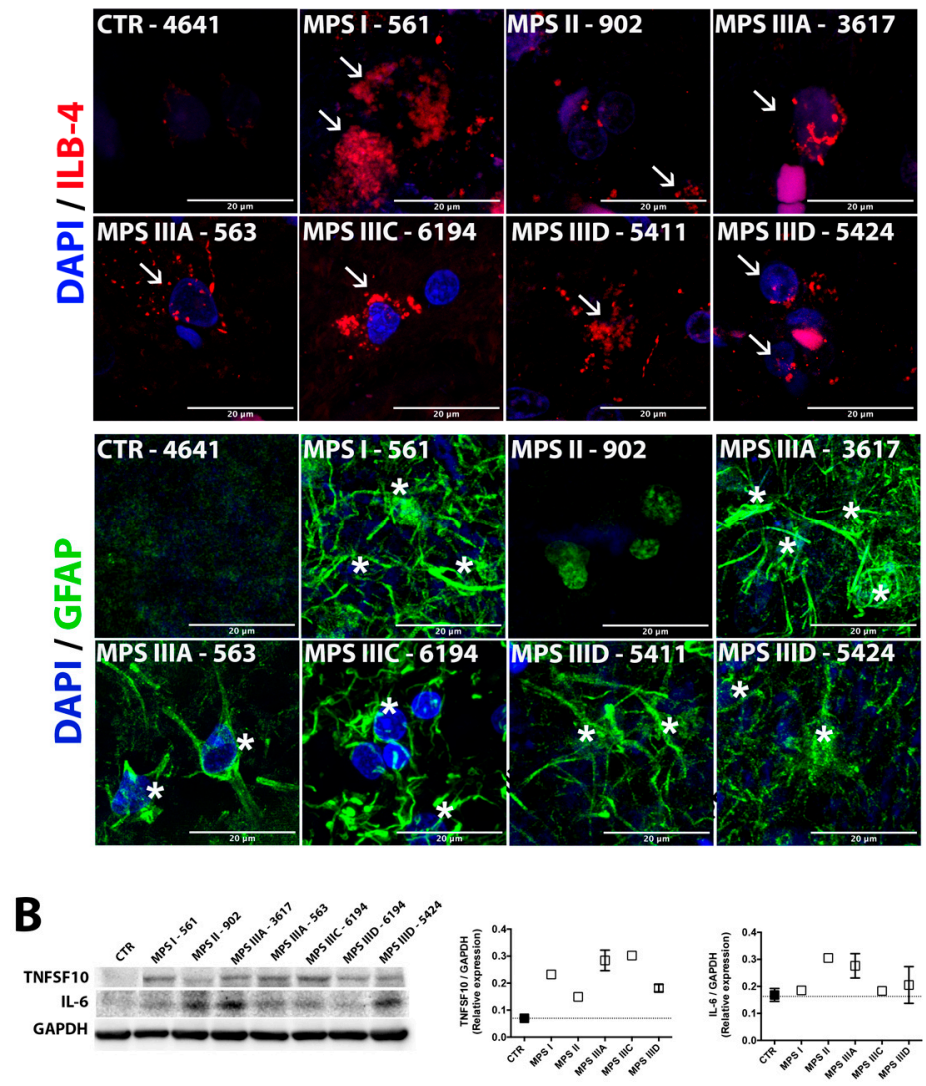

Figure 3. Astromicrogliosis in brain cortex tissues of human MPS patients is indicative of neuroinflammation. (A) Confocal microscopy images of brain cortex tissues of MPS I (561), MPS II (902), MPSIIIA (3617 and 563), MPS IIIC (6194), and MPS IIID (5411 and 5424) patients and a representative control (4641) stained with isolectin beta-4 (ILB-4,red) and antibodies against GFAP (green), markers for activated microglia and astrocytes, respectively. The fixed brain tissues of the MPS II patient HBCB1801OC were not sufficiently preserved to perform cryosectioning and conduct immunofluorescent analysis. DAPI (blue) was used as the nuclear counterstain. Activated microglia are marked with arrowheads and astrocytes are marked with asterisks; scale bar: $20 \mu \mathrm{m}$. (B) Western blotting analysis showing increased protein expression of the proinflammatory cytokines (tumor necrosis factor superfamily member 10 (TNFSF10) and interleukin 6 (IL-6) in the brain cortex protein extracts from MPS patients and combined controls $(662,754,1266,4641,5287,5813$, and 5977). Glyceraldehyde 3-phosphate dehydrogenase (GAPDH) was used as a loading control. Data are expressed as the mean \pm s.e.m.

\subsection{Autophagy Block and Neuronal Accumulation of Misfolded Proteins}

Impaired autophagy is a characteristic feature of cells in many lysosomal disorders [28]. It has been specifically shown for the neurons of the mouse models of neurological MPS disorders and proposed to be responsible for storage of misfolded protein aggregates, with accumulation of damaged nonfunctional mitochondria $[15,29]$. To test whether this is also the case for brain tissues from human MPS patients, we analyzed the distribution of light chain 3B protein (LC3B) in cortical neurons (Figure 4A). LC3B not detectable in the neurons of control brains has been localized to the cytoplasmic puncta in MPS neurons characteristic for the cells with impaired fusion of autophagosomes with lysosomes and increased number of autophagosomes containing secondary storage materials. 


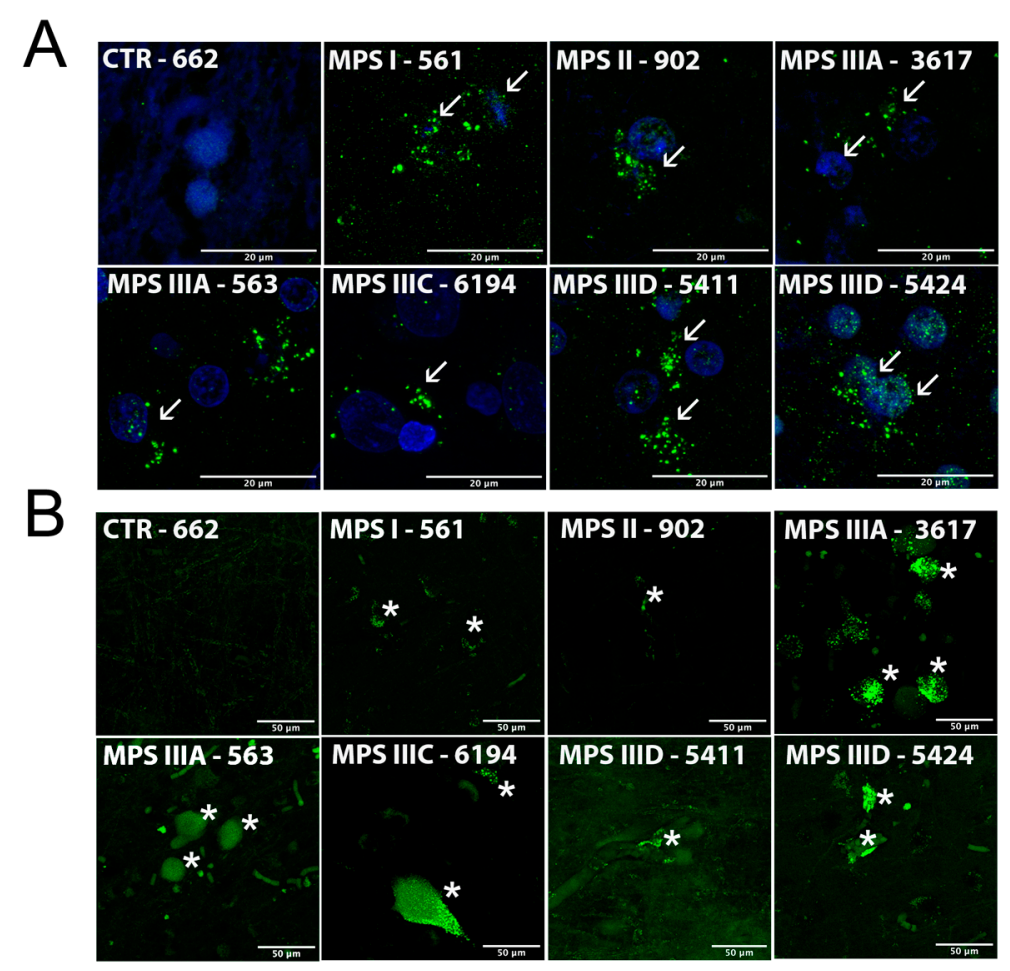

Figure 4. Impaired autophagic flux and accumulation of misfolded proteins in brain cortex tissues of human MPS patients. Representative confocal microscopy images showing (A) accumulation of light chain 3B protein (LC3B)-positive puncta (green) and (B) thioflavin S-positive protein aggregates (green) in brain cortex tissues from MPS I (561), MPS II (902), MPSIIIA (3617 and 563), MPS IIIC (6194), and MPS IIID (5411 and 5424) patients and a representative control (662). The fixed brain tissues of the MPS II patient HBCB1801OC were not sufficiently preserved to perform cryosectioning and conduct immunofluorescent analysis. DAPI (blue) was used as the nuclear counterstain. Neurons with LC3B puncta are marked with arrowheads and those stained with thioflavin S are markedwith asterisks. Scale bars: $20 \mu \mathrm{m}(\mathbf{A})$ and $50 \mu \mathrm{m}(\mathbf{B})$.

Neurons in the MPS brains showed increased fluorescence after staining with thioflavin $S$ (Figure 4B). This dye binds to beta sheet-rich structures and displays enhanced fluorescence, which is useful for detection of misfolded proteins and specifically amyloid aggregates in the brains of Alzheimer patients. The increased thioflavin staining is, therefore, suggestive of amyloid accumulation in the cortex of MPS patients, previously detected in the medial entorhinal cortex neurons of the mouse models of MPS I, IIIB, and IIIC.

\section{Discussion}

Our report identifies the neuronal accumulation of GAGs, GM2 and GM3 gangliosides, and misfolded proteins together with neuroinflammation as the hallmarks of CNS pathology in the neurological MPS disorders. All patients accumulated HS as detected by the increased levels of disaccharides $\mathrm{N}$ - or $\mathrm{O}$-sulfated at the nonreducing glucosamine residue. The MPS I and MPS II patients also showed a remarkable increase in DS because it was degraded by $\alpha$-L-iduronidase and iduronate sulfatase which are, respectively, affected in these diseases. All patients also demonstrated a significant $\sim 5$-fold reduction of mono-sulfated and di-sulfated KS. This result was completely unexpected since previous work showed increased KS levels in both blood plasma and urine of MPS I, II, III, VI, and VII patients [30,31]. Similarly, increased KS levels were also detected in blood from the mouse models of MPS I, MPS IIIA, and MPS VII and thought to be caused by secondary inhibition of the KS-degrading enzyme, $\mathrm{N}$-acetyl-galactose amine 6-sulfate sulfatase (GALNS), by the primary storage product, HS [32]. Other explanations for the secondary elevation of blood KS were also proposed, 
including the induction of KS synthesis by accumulated GAGs and/or inflammation, and its secretion into the circulation from damaged cartilage [33]. Importantly, the levels of blood KS correlate with the degree of skeletal dysplasia in several mouse MPS models, suggesting that secondary KS elevation may be responsible for the bone phenotype [32]. It is possible to speculate that the discrepancy in the direction of KS changes in the blood and the brain tissue can be related to the CNS damage and release of KS from destroyed brain cells into the blood or to the secondary inhibition of KS proteoglycan synthesis. Further studies are, therefore, necessary to identify both the mechanism underlying the strong KS reduction in the brain cortex of MPS patients and the potential pathological consequences of these changes.

Our results demonstrate the drastic alteration of GSL composition in patients with neurological forms of MPS I, II, IIIA, IIIC, and IIID. All these patients show a relative reduction of complex gangliosides (GM1a, GD1a, and GT1b) and an increase in simple (GM2, GM3) gangliosides as well as in neutral GSLs (Gb3, GA1, GA2, and LacCer). In contrast, in the patient with a nonneurological form of MPS II the sphingolipid composition was similar to that of normal controls. The increased levels of GM2 and GM3 gangliosides in the brain tissues were consistent with previously reported storage of these lipids in the mouse models of MPS IIIA, B, and C [13-15,28], but to our knowledge the marked increase of the neutral asialosphingolipids in the brains of MPS patients has not been reported previously.

The mechanism behind the secondary changes in brain sphingolipids is still discussed in the literature, and a majority of authors tend to agree that the accumulation of gangliosides in lysosomal storage disorders is related to the secondary impairment of autophagy/catabolism of autophagosomal content and lysosomal function. Direct evidence for the latter is still missing. It has been proposed to result from either the direct inhibition of lysosomal enzymes by accumulating substrates (e.g., GAGs) or from general disruption of the endolysosomal environment crucial for sphingolipid degradation ( $\mathrm{pH}$ change, lack of saposin-substrate interaction, etc.) [34]. Others have suggested that gangliosides accumulating in MPS are of nonlysosomal origin and are induced by altered Golgi function [35] or by distorted vesicular trafficking of lipids causing the build-up of exogenous LacCer in late endosomes and lysosomes [36,37]. Our data indicated that the changes were very specific for individual sphingolipids and consistent across multiple MPS, suggesting the involvement of common and precise biochemical mechanisms.

Neuroinflammation, thought to be triggered by HS storage affecting toll-like receptors (TLR) of microglia, was previously reported for all neurological MPS patients and mouse models (see, for example, [38]). It is recognized as an important component of the pathophysiological mechanism of the disease, although the work of Ausseil et al. demonstrated that, in TLR4-knockout MPS IIIB mice, neurodegeneration can occur independently of microglial activation suggesting the existence of alternative pathways [39]. Our current data demonstrated high levels of astromicroglyosis in the cortex of all MPS patients suggesting elevated neuroinflammation. Unfortunately, mRNA species were not entirely intact in all tissues studied, which prevented us from conducting RT-Q-PCR-based analysis of cytokines as we have done previously for the MPS IIIC mice [15]. However, Western blotting demonstrated increased levels of inflammatory cytokines, IL-6 and TNFSF10 (TRAIL), previously associated with neuroinflammation in humans. Interestingly, IL-6 levels were not increased in the mouse models of MPS I, IIIA, and IIIB [38].

Finally, increased thioflavin S staining suggested that cortical neurons of all MPS patients studied accumulated misfolded protein aggregates. While it is tempting to speculate that they can contain misfolded amyloid, this still needs to be experimentally verified. Although the degree of staining varied between the individual samples, the MPS patients showed the trend for an increase as compared with controls of the same age. Our previous data defined accumulation of densely packed material displaying a strong autofluorescence as a determining feature of brain neurons in MPS IIIC mice at the advanced stage of the disease [15]. These granules were positively stained with antibodies against the misfolded form of the subunit $C$ of mitochondrial adenosine triphosphate synthase (SCMAS), and 
their ultrastructural pattern strongly resembled that in neuronal ceroid lipofuscinoses suggesting that they are derived from autophagosomes and linking them to impaired autophagy. Our present data showed that all MPS patients and none of the controls showed the hallmark of the autophagy block, cytoplasmic LC3B-positive puncta.

Previously, we detected the specific sequence and pattern for the appearance of biomarkers of brain pathology in MPS IIIC mouse model: First GAGs in microglia, then neuroinflammation and neuronal ganglioside storage, followed by ceroid materials and neurodegeneration [15]. Based on this, we hypothesized that the disease starts with the accumulation of primary storage materials that induce general inflammation reactions in the brain, eventually leading to neuronal death [15]. Our current study identified the same biomarkers in post-mortem autopsy cortex samples of the human MPS I, II, IIIA, IIIC, and IIID patients suggesting that the pathological mechanism is common for all neurological MPS in humans and mice.

Author Contributions: Investigation, data analysis, and writing-original draft preparation, G.M.V. and S.K. Conceptualization, investigation, and writing_original draft preparation and editing, D.A.P. Conceptualization, supervision, and writing - review and editing, S.T. and F.M.P. Conceptualization, data analysis, supervision, and writing—original draft preparation, review, and editing, A.V.P. All authors have read and agreed to the published version of the manuscript.

Funding: This work has been partially supported by an operating grant PJT-156345 from the Canadian Institutes of Health Research, and gifts from JLK Foundation, Jonah's Just Began Foundation, and Sanfilippo Children's Research Foundation to A.V.P. G.M.V. is a recipient of a Scholarships Abroad's Program fellowship (BEPE) provided by Fundação de Amparo à Pesquisa do Estado de São Paulo (FAPESP \#2018/17003-6). F.M.P. is a Royal Society Wolfson Research Merit Award holder and a Wellcome Investigator in Science. This work was also supported by grants from The Carol Ann Foundation, Angelo R. Cali \& Mary V. Cali Family Foundation, Inc., The Vain and Harry Fish Foundation, Inc., The Bennett Foundation, Jacob Randall Foundation, Austrian and Japanese MPS societies, and Nemours Funds. S.T. was supported by an Institutional Development Award (IDeA) from the National Institute of General Medical Sciences of National Institutes of Health (grant number P30GM114736).

Acknowledgments: We acknowledge MPS patients, their families, and the NIH NeuroBioBank for the precious gift of brain tissues. We acknowledge Dr. Mila Ashmarina for critical reading of the manuscript and helpful advice, Rachel Heon-Roberts for the help with analysis of human brain tissues, and Dr. Nobuo Hanai, Dr. Akiko Furuya, and Kyowa Hakko Kirin Co., Ltd. for the gift of monoclonal antibodies against GM2 ganglioside.

Conflicts of Interest: The authors declare no conflict of interest. The funders had no role in the design of the study; in the collection, analyses, or interpretation of data; in the writing of the manuscript, or in the decision to publish the results.

\section{Abbreviations}

$\begin{array}{ll}\text { MPS } & \text { Mucopolysaccharidoses } \\ \text { GAG } & \text { Glycosaminoglycans } \\ \text { CNS } & \text { Central nervous system } \\ \text { ERT } & \text { Enzyme replacement therapy } \\ \text { HSCT } & \text { Hematopoietic stem cell transplantation } \\ \text { PAS } & \text { Periodic acid-Schiff } \\ \text { EM } & \text { Electron microscopy } \\ \text { HS } & \text { Heparan sulfate } \\ \text { DS } & \text { Dermatan sulfate } \\ \text { KS } & \text { Keratan sulfate } \\ \text { GERD } & \text { Gastroesophageal reflux disease } \\ \text { LFB } & \text { Luxol fast blue stain } \\ \text { HPLC } & \text { High performance liquid chromatography } \\ \text { DAPI } & \text { 4',6-diamidino-2-phenylindole } \\ \text { GFAP } & \text { Glial fibrillary acidic protein }\end{array}$




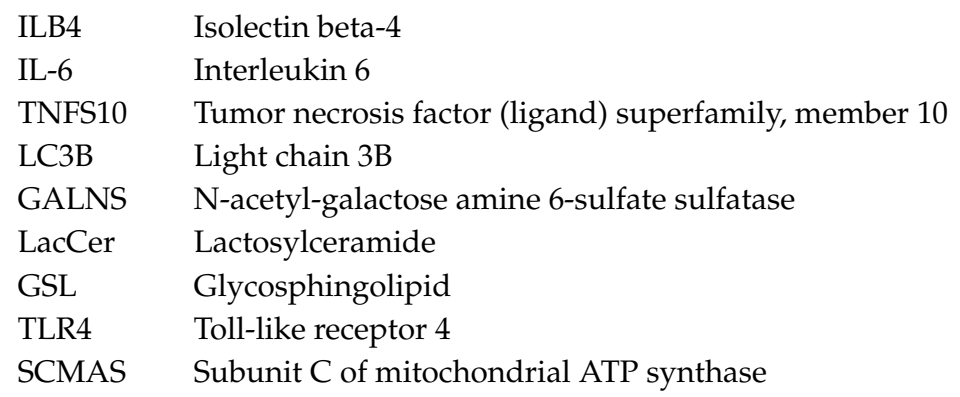

\section{References}

1. Meikle, P.J.; Hopwood, J.J.; Clague, A.E.; Carey, W.F. Prevalence of lysosomal storage disorders. JAMA 1999, 281, 249-254. [CrossRef] [PubMed]

2. Omar, A.; Jalil, J.A.; Shakrin, N.M.; Ngu, L.H.; Yunus, Z.M. Selective screening for detection of mucopolysaccharidoses in Malaysia; A two-year study (2014-2016). Mol. Genet. Metab. Rep. 2019, 19, 100469. [CrossRef] [PubMed]

3. Federhen, A.; Pasqualim, G.; de Freitas, T.F.; Gonzalez, E.A.; Trapp, F.; Matte, U.; Giugliani, R. Estimated birth prevalence of mucopolysaccharidoses in Brazil. Am. J. Med. Genet. A 2020, 10.1002/ajmg.a.61456. [CrossRef] [PubMed]

4. Giugliani, R.; Federhen, A.; Michelin-Tirelli, K.; Riegel, M.; Burin, M. Relative frequency and estimated minimal frequency of Lysosomal Storage Diseases in Brazil: Report from a Reference Laboratory. Genet. Mol. Biol. 2017, 40, 31-39. [CrossRef] [PubMed]

5. Neufeld, E.F.; Muenzer, J. The Mucopolysaccharidoses. In The Metabolic and Molecular Basis of Inherited Disease; Scriver, C.R., Beaudet, A.L., Sly, W.S., Valle, D., Eds.; McGraw-Hill: New York, NY, USA, 2001; pp. 3421-3452.

6. Valstar, M.J.; Ruijter, G.J.; van Diggelen, O.P.; Poorthuis, B.J.; Wijburg, F.A. Sanfilippo syndrome: A mini-review. J. Inherit. Metab. Dis. 2008, 31, 240-252. [CrossRef]

7. Eisengart, J.B.; King, K.E.; Shapiro, E.G.; Whitley, C.B.; Muenzer, J. The nature and impact of neurobehavioral symptoms in neuronopathic Hunter syndrome. Mol. Genet. Metab. Rep. 2020, 22, 100549. [CrossRef]

8. Scarpa, M.; Orchard, P.J.; Schulz, A.; Dickson, P.I.; Haskins, M.E.; Escolar, M.L.; Giugliani, R. Treatment of brain disease in the mucopolysaccharidoses. Mol. Genet. Metab. 2017, 122S, 25-34. [CrossRef]

9. Ginsberg, S.D.; Galvin, J.E.; Lee, V.M.; Rorke, L.B.; Dickson, D.W.; Wolfe, J.H.; Jones, M.Z.; Trojanowski, J.Q. Accumulation of intracellular amyloid-beta peptide (A beta 1-40) in mucopolysaccharidosis brains. J. Neuropathol. Exp. Neurol. 1999, 58, 815-824. [CrossRef]

10. Hamano, K.; Hayashi, M.; Shioda, K.; Fukatsu, R.; Mizutani, S. Mechanisms of neurodegeneration in mucopolysaccharidoses II and IIIB: analysis of human brain tissue. Acta Neuropathol. 2008, 115, 547-559. [CrossRef]

11. Ohmi, K.; Kudo, L.C.; Ryazantsev, S.; Zhao, H.Z.; Karsten, S.L.; Neufeld, E.F. Sanfilippo syndrome type B, a lysosomal storage disease, is also a tauopathy. Proc. Natl. Acad. Sci. USA 2009, 106, 8332-8337. [CrossRef]

12. Ohmi, K.; Zhao, H.Z.; Neufeld, E.F. Defects in the medial entorhinal cortex and dentate gyrus in the mouse model of Sanfilippo syndrome type B. PLoS ONE 2011, 6, e27461. [CrossRef] [PubMed]

13. Li, H.H.; Yu, W.H.; Rozengurt, N.; Zhao, H.Z.; Lyons, K.M.; Anagnostaras, S.; Fanselow, M.S.; Suzuki, K.; Vanier, M.T.; Neufeld, E.F. Mouse model of Sanfilippo syndrome type B produced by targeted disruption of the gene encoding alpha-N-acetylglucosaminidase. Proc. Natl. Acad. Sci. USA 1999, 96, 14505-14510. [CrossRef] [PubMed]

14. Bhaumik, M.; Muller, V.J.; Rozaklis, T.; Johnson, L.; Dobrenis, K.; Bhattacharyya, R.; Wurzelmann, S.; Finamore, P.; Hopwood, J.J.; Walkley, S.U.; et al. A mouse model for mucopolysaccharidosis type III A (Sanfilippo syndrome). Glycobiology 1999, 9, 1389-1396. [CrossRef] [PubMed]

15. Martins, C.; Hulkova, H.; Dridi, L.; Dormoy-Raclet, V.; Grigoryeva, L.; Choi, Y.; Langford-Smith, A.; Wilkinson, F.L.; Ohmi, K.; DiCristo, G.; et al. Neuroinflammation, mitochondrial defects and neurodegeneration in mucopolysaccharidosis III type C mouse model. Brain 2015, 138, 336-355. [CrossRef] [PubMed] 
16. Clarke, L.A.; Russell, C.S.; Pownall, S.; Warrington, C.L.; Borowski, A.; Dimmick, J.E.; Toone, J.; Jirik, F.R. Murine mucopolysaccharidosis type I: Targeted disruption of the murine alpha-L-iduronidase gene. Hum. Mol. Genet. 1997, 6, 503-511. [CrossRef]

17. Baldo, G.; Mayer, F.Q.; Martinelli, B.; Dilda, A.; Meyer, F.; Ponder, K.P.; Giugliani, R.; Matte, U. Evidence of a progressive motor dysfunction in Mucopolysaccharidosis type I mice. Behav. Brain Res. 2012, 233, $169-175$. [CrossRef]

18. Reolon, G.K.; Braga, L.M.; Camassola, M.; Luft, T.; Henriques, J.A.; Nardi, N.B.; Roesler, R. Long-term memory for aversive training is impaired in Idua(-/-) mice, a genetic model of mucopolysaccharidosis type I. Brain Res. 2006, 1076, 225-230. [CrossRef]

19. Bigger, B.W.; Begley, D.J.; Virgintino, D.; Pshezhetsky, A.V. Anatomical changes and pathophysiology of the brain in mucopolysaccharidosis disorders. Mol. Genet. Metab. 2018, 125, 322-331. [CrossRef]

20. Neville, D.C.; Coquard, V.; Priestman, D.A.; te Vruchte, D.J.; Sillence, D.J.; Dwek, R.A.; Platt, F.M.; Butters, T.D. Analysis of fluorescently labeled glycosphingolipid-derived oligosaccharides following ceramide glycanase digestion and anthranilic acid labeling. Anal. Biochem. 2004, 331, 275-282. [CrossRef]

21. Tettamanti, G.; Bonali, F.; Marchesini, S.; Zambotti, V. A new procedure for the extraction, purification and fractionation of brain gangliosides. Biochim. Biophys. Acta 1973, 296, 160-170. [CrossRef]

22. Nakamura, K.; Koike, M.; Shitara, K.; Kuwana, Y.; Kiuragi, K.; Igarashi, S.; Hasegawa, M.; Hanai, N. Chimeric anti-ganglioside GM2 antibody with antitumor activity. Cancer Res. 1994, 54, 1511-1516. [PubMed]

23. Fujitsuka, H.; Sawamoto, K.; Peracha, H.; Mason, R.W.; Mackenzie, W.; Kobayashi, H.; Yamaguchi, S.; Suzuki, Y.; Orii, K.; Orii, T.; et al. Biomarkers in patients with mucopolysaccharidosis type II and IV. Mol. Genet. Metab. Rep. 2019, 19, 100455. [CrossRef] [PubMed]

24. Metcalf, J.A.; Linders, B.; Wu, S.; Bigg, P.; O’Donnell, P.; Sleeper, M.M.; Whyte, M.P.; Haskins, M.; Ponder, K.P. Upregulation of elastase activity in aorta in mucopolysaccharidosis I and VII dogs may be due to increased cytokine expression. Mol. Genet. Metab. 2010, 99, 396-407. [CrossRef] [PubMed]

25. Kharbanda, S.; Panoskaltsis-Mortari, A.; Haddad, I.Y.; Blazar, B.R.; Orchard, P.J.; Cornfield, D.N.; Grewal, S.S.; Peters, C.; Regelmann, W.E.; Milla, C.E.; et al. Inflammatory cytokines and the development of pulmonary complications after allogeneic hematopoietic cell transplantation in patients with inherited metabolic storage disorders. Biol. Blood Marrow Transplant. 2006, 12, 430-437. [CrossRef]

26. Tisato, V.; Gonelli, A.; Voltan, R.; Secchiero, P.; Zauli, G. Clinical perspectives of TRAIL: Insights into central nervous system disorders. Cell. Mol. Life Sci. 2016, 73, 2017-2027. [CrossRef]

27. Hoffmann, O.; Zipp, F.; Weber, J.R. Tumour necrosis factor-related apoptosis-inducing ligand (TRAIL) in central nervous system inflammation. J. Mol. Med. (Berlin) 2009, 87, 753-763. [CrossRef]

28. Seranova, E.; Connolly, K.J.; Zatyka, M.; Rosenstock, T.R.; Barrett, T.; Tuxworth, R.I.; Sarkar, S. Dysregulation of autophagy as a common mechanism in lysosomal storage diseases. Essays Biochem. 2017, 61, 733-749. [CrossRef]

29. Ryazantsev, S.; Yu, W.H.; Zhao, H.Z.; Neufeld, E.F.; Ohmi, K. Lysosomal accumulation of SCMAS (subunit c of mitochondrial ATP synthase) in neurons of the mouse model of mucopolysaccharidosis III B. Mol. Genet. Metab. 2007, 90, 393-401. [CrossRef]

30. Tomatsu, S.; Okamura, K.; Maeda, H.; Taketani, T.; Castrillon, S.V.; Gutierrez, M.A.; Nishioka, T.; Fachel, A.A.; Orii, K.O.; Grubb, J.H.; et al. Keratan sulphate levels in mucopolysaccharidoses and mucolipidoses. J. Inherit. Metab. Dis. 2005, 28, 187-202. [CrossRef]

31. Tomatsu, S.; Shimada, T.; Mason, R.W.; Montano, A.M.; Kelly, J.; LaMarr, W.A.; Kubaski, F.; Giugliani, R.; Guha, A.; Yasuda, E.; et al. Establishment of glycosaminoglycan assays for mucopolysaccharidoses. Metabolites 2014, 4, 655-679. [CrossRef]

32. Rowan, D.J.; Tomatsu, S.; Grubb, J.H.; Montano, A.M.; Sly, W.S. Assessment of bone dysplasia by micro-CT and glycosaminoglycan levels in mouse models for mucopolysaccharidosis type I, IIIA, IVA, and VII. J. Inherit. Metab. Dis. 2013, 36, 235-246. [CrossRef] [PubMed]

33. Tomatsu, S.; Kubaski, F.; Sawamoto, K.; Mason, R.W.; Yasuda, E.; Shimada, T.; Montano, A.M.; Yamaguchi, S.; Suzuki, Y.; Orii, T. Newborn screening and diagnosis of mucopolysaccharidoses: Application of tandem mass spectrometry. Nihon Masu Sukuriningu Gakkai Shi 2014, 24, 19-37. [PubMed]

34. Walkley, S.U.; Vanier, M.T. Secondary lipid accumulation in lysosomal disease. Biochim. Biophys. Acta 2009, 1793, 726-736. [CrossRef] [PubMed] 
35. Roy, E.; Bruyere, J.; Flamant, P.; Bigou, S.; Ausseil, J.; Vitry, S.; Heard, J.M. GM130 gain-of-function induces cell pathology in a model of lysosomal storage disease. Hum. Mol. Genet. 2012, 21, 1481-1495. [CrossRef]

36. Marks, D.L.; Pagano, R.E. Endocytosis and sorting of glycosphingolipids in sphingolipid storage disease. Trends Cell Biol. 2002, 12, 605-613. [CrossRef]

37. Sillence, D.J.; Platt, F.M. Glycosphingolipids in endocytic membrane transport. Semin. Cell Dev. Biol. 2004, 15, 409-416. [CrossRef]

38. Wilkinson, F.L.; Holley, R.J.; Langford-Smith, K.J.; Badrinath, S.; Liao, A.; Langford-Smith, A.; Cooper, J.D.; Jones, S.A.; Wraith, J.E.; Wynn, R.F.; et al. Neuropathology in mouse models of mucopolysaccharidosis type I, IIIA and IIIB. PLoS ONE 2012, 7, e35787. [CrossRef]

39. Ausseil, J.; Desmaris, N.; Bigou, S.; Attali, R.; Corbineau, S.; Vitry, S.; Parent, M.; Cheillan, D.; Fuller, M.; Maire, I.; et al. Early neurodegeneration progresses independently of microglial activation by heparan sulfate in the brain of mucopolysaccharidosis IIIB mice. PLOS ONE 2008, 3, e2296. [CrossRef]

(C) 2020 by the authors. Licensee MDPI, Basel, Switzerland. This article is an open access article distributed under the terms and conditions of the Creative Commons Attribution (CC BY) license (http://creativecommons.org/licenses/by/4.0/). 